\title{
Effects of donor age on urinary chemosignals that influence the timing of first oestrus in young female house mice, Mus domesticus
}

\author{
L. C. Drickamer \\ Department of Zoology, Southern Illinois University, Carbondale, Illinois 62901, U.S.A.
}

\begin{abstract}
Summary. The effects of donor age on the effectiveness of puberty-influencing urinary chemosignals in wild house mice was tested in a series of 3 experiments. The chemosignal from male mice that accelerates puberty was present in the urine from about the time of puberty and throughout the normal lifespan, but declined about 1 year of age. Oestrous females released a substance in their urine that accelerates puberty in young females. This substance remained effective from first oestrus until over 1 year of age, although older females were in oestrus less frequently than younger mice. Females that are pregnant or lactating released a puberty-accelerating substance in their urine regardless of age. Production and release of the puberty-delaying chemosignal by grouped females was initiated before puberty and continued throughout the lifespan of the mouse.
\end{abstract}

Keywords: mouse; chemosignals; puberty; first oestrus; age; pregnancy; lactation

\section{Introduction}

There are at least 4 known urinary chemosignals that influence the timing of first vaginal oestrus in young female house mice. Urine from male mice, from oestrous female mice and from pregnant or lactating female mice all accelerate the onset of first oestrus (Vandenbergh, 1969; Colby \& Vandenbergh, 1974; Drickamer \& Hoover, 1979; Drickamer, 1986a), whereas urine from grouped females delays first oestrus (Vandenbergh et al., 1972; Drickamer, 1974, 1977). The pubertyaccelerating chemosignal in male mouse urine is androgen-dependent, being absent from the urine of castrated or prepubertal males, and reappearing when adult castrated males are given hormone replacement therapy (Colby \& Vandenbergh, 1974; Lombardi \& Vandenbergh, 1977; Drickamer \& Murphy, 1978). The puberty-delaying chemosignal is present in the urine of juvenile as well as adult females (Drickamer, 1977).

No one has yet tested whether the release of the urinary chemosignals changes from puberty until senescence. The 3 experiments presented here were designed to test whether there are any changes in the release of the puberty-influencing chemosignals over the lifespan of the mouse.

\section{Materials and General Methods}

The mice used in these experiments were of two types. Wild stock animals, born to mice (Mus domesticus) caught at Simsbury, Connecticut, U.S.A., served as urine donors to assess the effects of ageing on release of the urinary chemosignals and ICR/Alb laboratory mice served as test subjects. All mice of both stocks were maintained in shoe-box cages of polypropylene measuring $15 \times 28 \times 15 \mathrm{~cm}$ deep with opaque sides and fitted wire lids. A bedding of ground wood shavings was changed once each week. Pregnant and lactating females and young mice were provided with cotton for making nests. Wayne Lab Blox and water were supplied ad libitum to all mice throughout the experiments. All cages were maintained in the same room at $21^{\circ} \mathrm{C}-25^{\circ} \mathrm{C}$ and $30-60 \%$ relative humidity on a $12 \mathrm{~h}$ light:12 $\mathrm{h}$ dark daily regime with overhead fluorescent lights on from 06:00 to 18:00 h. 
To provide young test females for the first two experiments, two adult virgin females, aged $90-150$ days, were paired with fertile adult males. Pregnant females were isolated in individual cages earlier than 7 days before parturition. All cages were checked daily, and births were recorded. On the day after birth, each litter was counted and all of the young were sexed. Each litter was reduced to exactly 10 young, including at least 3 , but not more than 7 , male young. Litters of fewer than 10 young were discarded. Mice were weaned at 21 days after birth and were immediately assigned, at random, to an experiment and treatment.

To determine puberty, test females were monitored daily until the occurrence of vaginal introitus after which a daily vaginal smear was taken. The wet-mount vaginal smears were examined immediately using a light microscope and the cellular contents were judged to determine the stage of the oestrous cycle according to the criteria of Rugh (1968) and Vandenbergh (1969).

\section{Detailed Methods and Results}

\section{Experiment I}

Methods. This experiment was designed to assess whether there are any changes in the release of the urinary chemosignals from males or females in oestrus that accelerate female puberty or the signal from grouped females that delays puberty. To test the effects of age on the presence of the puberty-accelerating chemosignal from males, 7 treatment groups were used. For each treatment, 30 young test females were caged individually and painted daily on the external nares with water, or urine from individually caged adult wild stock males aged 20-40 days, 50-70 days, 80-100 days, 130-170 days, 200-240 days, or 360-400 days. Fresh urine was collected daily for each treatment from a battery of 12-18 individually caged wild stock adult males. Urine was collected by holding each donor mouse over a Petri dish and gently squeezing the flanks. Pooled urine samples were collected daily from at least 6 donor mice for each treatment condition. Urine treatment consisted of 34 strokes of a small paintbrush on the external nares $(\sim 0.05 \mathrm{ml}$ is transferred in this manner) and lasted for 10 days, starting on Day 21 of age. Separate Petri dishes and paintbrushes were maintained for each treatment.

Procedures for testing the urine from grouped females were identical to those described for testing male urine, except that the donors were groups of 6 females/cage for each age interval and 4-6 such cages were maintained for each treatment. Females were caged together for at least 10 days before being used as donors, with the exception of females in the youngest age group, for which only 5 days of group housing were possible before the start of urine collection.

The procedures for testing the urine from females in oestrus were identical to those described above with two exceptions. The donor females consisted of batteries of 20-30 females per treatment. Vaginal smears were taken daily and urine was collected only from females that were in oestrus. No females were tested for the age interval 25-40 days since no wild stock females had attained puberty at such early ages.

Results. For urine from males, there was an overlapping pattern of significant differences for the mean ages at puberty of the mice in the various treatments (Table 1). Females treated with water or with urine from males aged $25-40$ days did not differ from one another and resulted in significantly later puberty for the test females than did treatments using urine from males in age intervals from 80-100 through 200-240 days. Urine from males aged 50-70 days or 360-400 days produced mean ages for puberty for females that were intermediate between the control value and the urine treatments that resulted in accelerated puberty.

All treatments using urine from grouped females resulted in mean ages at first vaginal oestrus that were significantly later than those of the water-treated controls (Table 1).

For urine from oestrous females, all treatments resulted in mean ages at first vaginal oestrus that were significantly earlier than those of the water-treated controls (Table 1).

\section{Experiment II}

Methods. This experiment was designed to test whether there are any age-related changes in the release of the urinary chemosignal from pregnant or lactating females that accelerates the onset of 
Table 1. Mean ages (days \pm 1 s.e.m., 30 mice/treatment) of first vaginal oestrus in laboratory female house mice treated with water or urine from wild-stock males, grouped females (6/cage), or females in oestrus, when the donors are of different ages at the time of urine collection

\begin{tabular}{|c|c|c|c|}
\hline \multirow[b]{2}{*}{$\begin{array}{c}\text { Donor age } \\
\text { (days) }\end{array}$} & \multicolumn{3}{|c|}{ Urine source } \\
\hline & Males & $\begin{array}{l}\text { Grouped } \\
\text { females }\end{array}$ & $\begin{array}{l}\text { Females } \\
\text { in oestrus }\end{array}$ \\
\hline $25-40$ & $35 \cdot 2(0.7)^{\mathrm{c}}$ & $40 \cdot 3(0 \cdot 5)^{b}$ & 一 \\
\hline $50-70$ & $32.9(0.5)^{b c}$ & $40.9(0.7)^{b}$ & $30.7(0.6)^{a}$ \\
\hline $80-100$ & $30.5(0.6)^{\mathrm{ab}}$ & $39.2(0.6)^{b}$ & $29.4(0.5)^{a}$ \\
\hline $130-170$ & $31.0(0.7)^{\mathrm{ab}}$ & $39.2(0.7)^{b}$ & $31.0(0 \cdot 7)^{a}$ \\
\hline $200-240$ & $30.5(0.6)^{a b}$ & $38.8(0.4)^{b}$ & $30.7(0.5)^{a}$ \\
\hline $360-400$ & $30 \cdot 2(0 \cdot 5)^{\mathrm{ab}}$ & $39 \cdot 5(0 \cdot 5)^{b}$ & $29.9(0.5)^{a}$ \\
\hline Control (water) & $34 \cdot 7(0 \cdot 7)^{\mathrm{c}}$ & $35 \cdot 7(0 \cdot 6)^{\mathrm{a}}$ & $35.5(0 \cdot 7)^{b}$ \\
\hline$F(d . f .=6,203)=$ & $\begin{array}{c}9.91 \\
P<0.001\end{array}$ & $\begin{array}{c}\quad 6.56 \\
P<0.001\end{array}$ & $\begin{array}{c}11.95 \\
P<0.001\end{array}$ \\
\hline
\end{tabular}

Means in the same vertical column not marked with the same superscript letter are significantly different at the 0.05 level by Tukey's w-procedure (Steel \& Torrie, 1960).

first oestrus in young female mice. To test the effects of age on the presence of the pubertyaccelerating chemosignal from pregnant females, 6 treatment groups were used. For each treatment, 30 young test females were caged individually and painted daily on the external nares with water, or urine from adult wild-stock pregnant females, individually caged and aged 50-80, $100-130,200-230,300-330$ or 400-430 days. Fresh urine was collected daily for each treatment. Urine collection and treatment procedures were identical to those used in Exp. I.

For each designated treatment age interval, separate batteries of 11-16 females were maintained. The pregnant females were obtained by pairing females with fertile males and checking daily for the presence of a vaginal plug. Upon detection of the vaginal plug, the male was removed. The pregnant females were used for urine collection starting on Day 7 of pregnancy (see Drickamer, 1983).

To test the effects of age on urine from lactating females, the methods were identical to those described for pregnant females, except that the donor mice were from batteries of 9-15 lactating females. Urine was collected from these donors only from 7 to 21 days after parturition (see Drickamer, 1983).

Results. For urine from pregnant females, there was an overlapping pattern of significant differences in mean age at first oestrus, although all urine treatments resulted in accelerted puberty relative to the water-treated controls (Table 2). Mice treated with urine from pregnant females $50-80$ or $400-430$ days old attained puberty earlier than did females treated with urine from pregnant mice 100-130 days old. Urine from females $200-230$ or 300-330 days old produced mean ages of puberty that were intermediate between and overlapping with the other test conditions.

All of the treatments with urine from lactating females resulted in mean ages for first oestrus that were significantly earlier than the control treatment (Table 2).

\section{Experiment III}

Methods. In Exp. I, urine from oestrous females was effective in accelerating puberty in young females, regardless of the age of the donor. However, the ability of older females to accelerate puberty in young females through a urinary chemosignal may also depend on the frequency with 
Table 2. Mean ages ( \pm 1 s.e.m., 30 mice/treatment) for first vaginal oestrus in laboratory female house mice treated with water or urine from wildstock pregnant, or lactating females, when the donors are of different ages at the time of urine collection

\begin{tabular}{lcc}
\hline & \multicolumn{2}{c}{ Urine source } \\
\cline { 2 - 3 } $\begin{array}{c}\text { Donor age } \\
\text { (days) }\end{array}$ & $\begin{array}{c}\text { Pregnant } \\
\text { females }\end{array}$ & $\begin{array}{c}\text { Lactating } \\
\text { females }\end{array}$ \\
\hline $50-80$ & $29 \cdot 6(0 \cdot 7)^{\mathrm{a}}$ & $30 \cdot 2(0 \cdot 6)^{\mathrm{a}}$ \\
$100-130$ & $32.6(0 \cdot 7)^{\mathrm{b}}$ & $29 \cdot 7(0 \cdot 4)^{\mathrm{a}}$ \\
$200-230$ & $30 \cdot 4(0 \cdot 4)^{\mathrm{ab}}$ & $30 \cdot 0(0 \cdot 4)^{\mathrm{a}}$ \\
$300-330$ & $30 \cdot 5(0 \cdot 5)^{\mathrm{ab}}$ & $29 \cdot 0(0 \cdot 4)^{\mathrm{a}}$ \\
$400-430$ & $30 \cdot 1(0 \cdot 5)^{\mathrm{a}}$ & $31 \cdot 0(0 \cdot 6)^{\mathrm{a}}$ \\
Control (water) & $35 \cdot 3(0 \cdot 7)^{\mathrm{c}}$ & $36 \cdot 9(0 \cdot 7)^{\mathrm{b}}$ \\
F (d.f. = 5,174) $=$ & $15 \cdot 05$ & $8 \cdot 34$ \\
& $P<0 \cdot 00 \mathrm{I}$ & $P<0 \cdot 001$ \\
\hline
\end{tabular}

Means in the same vertical column not marked by the same superscript letter are significantly different at the 0.05 level by Tukey's w-procedure.

which these older females are in oestrus. This experiment examined the effects of ageing on the frequency of oestrous cycles in wild stock female mice.

Five treatment groups, each consisting of 30 individually caged adult females (wild stock) were used for this test. The 5 groups involved females aged $50-80,120-150,220-250,320-350$ and $420-450$ days. A vaginal smear was taken daily for 30 days and both the number of days the females were in oestrus and the number of complete oestrous cycles were recorded.

Results. For both dependent variables there were similar patterns of significant differences among the treatment means (Table 3). Mice 50-80 or 420-450 days old had fewer days of oestrus and fewer oestrous cycles during the 30 -day test period than did mice from the other three age intervals.

Table 3. Mean number of days and mean number of oestrous cycles ( \pm 1 s.e.m., 30 mice/treatment) for wild-stock female mice during a 30-day test period at the prescribed age interval

\begin{tabular}{ccc}
\hline $\begin{array}{c}\text { Female age range } \\
\text { (days) }\end{array}$ & $\begin{array}{c}\text { No. of days } \\
\text { in oestrus }\end{array}$ & $\begin{array}{c}\text { No. of } \\
\text { oestrous cycles }\end{array}$ \\
\hline $50-80$ & $7 \cdot 8(0 \cdot 4)^{\mathrm{a}}$ & $3 \cdot 7(0 \cdot 3)^{\mathrm{a}}$ \\
$120-150$ & $10 \cdot 5(0 \cdot 5)^{\mathrm{b}}$ & $4 \cdot 9(0 \cdot 4)^{\mathrm{b}}$ \\
$220-250$ & $10 \cdot 3(0 \cdot 4)^{\mathrm{b}}$ & $5 \cdot 1(0 \cdot 4)^{\mathrm{b}}$ \\
$320-350$ & $10 \cdot 2(0 \cdot 6)^{\mathrm{b}}$ & $4 \cdot 8(0 \cdot 3)^{\mathrm{b}}$ \\
$420-450$ & $6 \cdot 5(0 \cdot 4)^{\mathrm{a}}$ & $3 \cdot 4(0 \cdot 3)^{\mathrm{a}}$ \\
F (d.f. $=4,145)=$ & $7 \cdot 26$ & $9 \cdot 25$ \\
& $P<0 \cdot 001$ & $P<0 \cdot 001$ \\
\hline
\end{tabular}

Means not marked by the same superscript letter are significantly different at the 0.05 level by Tukey's w-procedure. 


\section{Discussion}

Several conclusions may be drawn based upon the foregoing series of experiments. For the pubertyaccelerating chemosignals contained in the urine of oestrous females, lactating females and probably pregnant females, and the puberty-delaying substance in the urine of grouped females, there are no changes in the presence of the chemosignals in the urine with increasing age. For male mice, release of the puberty-accelerating urinary chemosignal apparently declines at about 1 year of age. Data on wild house mice (Berry \& Jakobson, 1971; Bellamy, 1981) indicate that there is very high mortality within the first 6 months of life and then a gradual decline in numbers thereafter, with measurable numbers still alive after $15-18$ months. In a natural population, the older, reproducing mice that have survived the initial months of life, may in fact have life expectancies of about 1 year.

Prepubertal females do not exhibit oestrous cycles and would therefore not be expected to release the puberty-accelerating signal. Likewise, females that are not pregnant or lactating would not be expected to release the puberty-accelerating substance(s) associated with those particular reproductive conditions. Once puberty has been attained and cycles of pregnancy and lactation commence, the release of these puberty-accelerating signals continues throughout the natural lifespan of the mice as long as they are in the appropriate hormonal condition. However, as Exp. III illustrates, the frequency with which the female is in oestrus declines with age. So too, the rate of pregnancy and the frequency with which the female is lactating might be expected to decline as senescence approaches. The frequency with which a female would be releasing these pubertyaccelerating urinary chemosignals into the environment might also therefore be expected to decline.

Drickamer (1977) has previously shown that juvenile as well as adult female mice will release the puberty-delaying urinary chemosignal when they are housed in groups. This signal is apparently released starting at or before the mice are weaned and continues throughout the lifespan of the house mouse. Thus, if the release of the signal from grouped females is taken to be a modulating influence effecting changes, through endocrinological pathways, in rates of reproduction and possibly population growth (Drickamer, 1986b), the production and release of the signal would be triggered by appropriate density conditions, regardless of the age of the mouse.

The signal in male mouse urine that accelerates female puberty is androgen-dependent (Colby $\&$ Vandenbergh, 1974; Drickamer \& Murphy, 1978). Very young mice, aged 25-40 days, have generally not yet attained puberty and therefore would not be expected to release the pubertyaccelerating urinary chemosignal. Wild male house mice, aged 50-70 days, are generally past puberty and sexually active (L. C. Drickamer, unpublished). Why then, in Exp. I, urine from males $50-70$ days of age did not produce the expected full acceleration of puberty is difficult to explain. Possibly, some of the males were not yet pubertal, but even if only a few were past puberty, there should have been sufficient acceleratory chemosignal in the daily pooled urine collection to result in a complete effect on young females because the puberty-accelerating substance is effective in very small daily doses (Drickamer, 1982, 1984). Another possibility is that young males just past puberty do not produce/release a puberty-accelerating chemosignal having the same potency as at somewhat older ages. This potential qualitative effect might be difficult to further dissect. Lastly, since the mean age for puberty in this treatment group is actually intermediate between the control value and treatment means involving full puberty acceleration, some form of experimental (e.g. Type I) error may be involved.

There is some decline in the effectiveness of the puberty-accelerating urinary chemosignal with age. Earlier investigators have reported declines in sexual arousal, sexual behaviour, concentrations of various hormones, and fertility in various stocks of mice correlated with increasing age (Hafez, 1976; Leatham, 1977; Bronson \& Desjardins, 1977; Huber et al., 1980; Craigen \& Bronson, 19:3:.). Much of this evidence points to a decline in androgen production and/or circulation in the older male mice. The observed decline in release of the puberty-accelerating chemosignal in Exp. I may 
be another manifestation of this shift in hormone release patterns that occurs with increasing age. However, for the wild-stock house mice tested here, the decline does not begin until the mice are about 1 year of age, and even then the decline is apparently not total. It may well be that, under natural conditions, the male mice release the puberty-accelerating chemosignal throughout their normal lifespan which is less than 1 year (Bellamy, 1981).

This research was supported by U.S. Public Health Service Grant Award No. HD-08585 and by National Science Foundation Award No. BNS-8516331. I thank Williams College for providing the facilities and the animal care support personnel.

\section{References}

Bellamy, D. (1981) Ageing: with particular reference to the use of the house mouse as a mammalian model. Symp. zool. Soc. Lond. 47, 267-300.

Berry, R.J. \& Jakobson, M.E. (1971) Life and death in an island population of the house mouse. Expl. Geront. 6, 187-197.

Bronson, F.H. \& Desjardins, C. (1977) Reproductive failure in aged CBF 1 male mice: interrelationships between pituitary gonadotrophic hormones, testicular function, and mating success. Endocrinology 101, 939-945.

Colby, D.R. \& Vandenbergh, J.G. (1974) Regulatory effects of urinary pheromones on puberty in the mouse. Biol. Reprod. 11, 268-279.

Craigen, W. \& Bronson, F.H. (1982) Deterioration of the capacity for sexual arousal in aged male mice. Biol. Reprod. 26, 869-874.

Drickamer, L.C. (1974) Sexual maturation of female mice: social inhibition. Devl Psychobiol. 7, 257-265.

Drickamer, L.C. (1977) Delay of sexual maturation in female house mice by exposure to grouped females or urine from grouped females. J. Reprod. Fert. 51, $77-81$.

Drickamer, L.C. (1982) Acceleration and delay of first vaginal oestrus in female mice by urinary chemosignals: dose levels and mixing of urine sources. Anim. Behav. 30, 456-460.

Drickamer, L.C. (1983) Chemosignal effects on puberty in young female mice: urine from pregnant and lactating females. Devl Psychobiol. 16, 207-217.

Drickamer, L.C. (1984) Effects of very small doses of urine on acceleration and delay of sexual maturation in female house mice. J. Reprod. Fert. 71, 475-477.

Drickamer, L.C. (1986a) Effects of urine from females in oestrus on puberty in female mice. J. Reprod. Fert. 77,613622 .

Drickamer, L.C. (1986b) Puberty-influencing chemosignals in mice: ecological and evolutionary considerations. In Chemical Signals in Vertebrates, vol. 4, pp. 441-455. Eds D. Duvall, D. Muller-Schwarze \& R. M. Silverstein, Plenum, New York.

Drickamer, L.C. \& Hoover, J.E. (1979) Effects of urine from pregnant and lactating female house mice on sexual maturation of juvenile females. Devl Psychobiol. 12, 545-551.

Drickamer, L.C. \& Murphy, R.X. (1978) Female mouse maturation: effects of excreted and bladder urine from juvenile and adult males. Devl Psychobiol. 11, 63-72.

Hafez, E.S.E. (1976) Aging and Reproductive Physiology. Ann Arbor Science Press, Ann Arbor.

Huber, M.H.R., Bronson, F.H. \& Desjardins, C. (1980) Sexual activity of aged male mice: correlation with level of arousal, physical endurance, pathological status, and ejaculatory capacity. Biol. Reprod. 23, 305-316.

Leatham, J.H. (1977) Aging and the testis. In The Testis, vol. 4, pp. 547-558. Eds A. D. Johnson, W. R. Gomes \& N. L. VanDemark. Academic Press, New York.

Lombardi, J.L. \& Vandenbergh, J.G. (1977) Pheromonally induced sexual maturation in females: regulation by the social environment of the male. Science, N.Y. 196, 545-546.

Rugh, R. (1968) The Mouse, Its Reproduction and Development. Burgess, Minneapolis.

Steel, R.G.D. \& Torrie, J.H. (1960) Principles and Procedures of Statistics. McGraw-Hill Book Co., New York.

Vandenbergh, J.G. (1969) Male odor accelerates female sexual maturation in mice. Endocrinology 84, $658-660$.

Vandenbergh, J.G., Drickamer, L.C. \& Colby, D.R. (1972) Social and dietary factors in the sexual maturation of female mice. J. Reprod. Fert. 28, $397-405$.

Received 4 December 1987 